\title{
EFEKTIVITAS MODEL PEMBELAJARAN KOOPERATIF TIPE SNOWBALL THROWING TERHADAP HASIL BELAJAR MATEMATIKA SISWA
}

\section{EFFECTIVENESS OF THE COOPERATIVE LEARNING MODEL SNOWBALL THROWING TYPE ON STUDENTS' MATHEMATICS LEARNING OUTCOMES}

\author{
Karlina $^{1}$, Fitrah Amelia ${ }^{2}$ \\ ${ }^{1,2}$ Program Studi Pendidikan Matematika, Fakultas Keguruan dan Ilmu Pendidikan \\ Universitas Riau Kepulauan, Batam, Kepulauan Riau, Indonesia \\ 2email: fitrahamelia@yahoo.com
}

\begin{abstract}
ABSTRAK
Penelitian ini bertujuan untuk mengetahui efektivitas model pembelajaran kooperatif tipe Snowball Throwing terhadap hasil belajar matematika siswa. Jenis penelitian preeksperimen dengan desain penelitian One-Group Pre-test-Post-test Design. Populasi penelitian ini adalah XI SMKIT DBS 01 Batam Tahun Pelajaran 2018/2019. Teknik pengambilan sampel dilakukan dengan teknik sampling jenuh dengan banyak siswa 19 siswa. Jenis tes yang diberikan adalah tes uraian sebanyak 8 soal pre-test dan 8 soal post-test yang kemudian dilakukan analisis instrumen menggunakan validitas konstruk dan reliabilitas sehingga didapat 8 soal yang valid dan reliabel dengan nilai reliabel pre-test 0,684 dan post-test 0,724 untuk menjadi soal pre-test dan post-test. Uji normalitas menggunakan Kolmogorov Smirnov teramati hasil data pre-test dan post-test normal. Pengujian hipotesis dilakukan dengan menggunakan uji $t$ dua sampel berkorelasi diperoleh nilai sig. $(0.00) \leq \alpha(0,05)$. Hasil penelitian tersebut menunjukan bahwa model pembelajaran kooperatif tipe snowball throwing efektif terhadap hasil pembelajaran matematika siswa.
\end{abstract}

Kata Kunci: Snowball Throwing, Hasil Belajar Matematika Siswa.

\section{ABSTRACT}

This research aims to determine the effectiveness of the cooperative learning model Snowball Throwing type on students' mathematics learning outcomes. This type of research is a research experiment with research design One-Group Pre-test-Post-test Design. The population of this study was XI SMKIT DBS 01 Batam Academic Year 2018/2019. The sampling technique is done by saturating sampling techniques with many students 19 students. The type of test given is a descriptive test consisting of 8 pre-test questions and 8 post-test questions which then analyze the instrument using construct validity and reliability so that 8 valid and reliable questions are obtained with reliable values of pre-test " 0.684 " and post-test " 0.724 " to be a matter of pre-test and posttest. Normality test using Kolmogorov Smirnov obtained the results of normal pre-test and post-test data. Hypothesis testing is done using the t test two correlated samples obtained sig. $(0.00) \leq \alpha(0.05)$. The results of this study indicate that the cooperative learning model of the snowball throwing type is effective against students' mathematics learning outcomes.

Keywords: Snowball Throwing, Student Mathematics Learning Outcomes.

\section{PENDAHULUAN}

Matematika merupakan pembelajaran yang bersifat universal dan berperan penting dalam perkembangan teknologi modern dan juga berperan penting untuk meningkatkan daya pikir manusia dalam kehidupan sehari-hari. Universal berarti matematika merupakan ilmu induk yang dapat diaplikasikan pada cabang ilmu lainnya. Sehingga tidak heran jika matematika dipelajari secara luas dan mendasar sejak jenjang pendidikan sekolah dasar. 
Karlina dan Amelia: Efektivitas Model Pembelajaran Kooperatif ...

Mengingat pentingnya matematika dalam kehidupan sehari-hari dan telah dipelajari mulai dari jenjang sekolah dasar, siswa diharapkan sudah terbiasa untuk berpikir secara matematis dan dapat mengaplikasikan konsep-konsep yang sudah dipelajari dalam matematika untuk memecahkan masalah-masalah dalam kehidupan sehari-hari. Namun, menurut Suhendri (2012:29) di lapangan siswa masih beranggapan bahwa matematika merupakan pelajaran yang sulit, sukar, dan menegangkan, karena sebagian besar guru matematika yang berpenampilan kurang familiar atau terlalu serius. Terkadang juga, guru mengalami kesulitan dalam menyampaikan materi kepada peserta didik, sehingga hasil belajar yang diperoleh peserta didik pada pelajaran matematika terbilang rendah (Munawaroh \& Alamuddin, 2014:164).

Hasil belajar adalah kemampuan yang diperoleh atau dimiliki siswa setelah melalui pengalaman belajar, yang berupa kemampuan kognitif, afektif dan psikomotorik yang disebabkan oleh pengalaman. Hasil belajar bermanfaat untuk mengetahui sejauh mana siswa dapat menyerap materi pembelajaran dan hasil belajar juga akan menentukan apakah siswa tersebut harus mengikuti remedial (perbaikan) atau pengayaan. Remedial diberikan kepada siswa yang hasil belajarnya rendah sedangkan pengayaan diberikan kepada siswa yang hasil belajarnya tinggi atau melebihi rata-rata yaitu dengan cara diberikan materi yang lebih mendalam lagi.

Berdasarkan hasil observasi yang dilakukan peneliti selama Pengalaman Praktek Lapangan (PPL) di kelas X SMKIT Darussalam Boarding School (DBS) 01 Batam, bahwa pembelajaran masih berpusat pada guru. Guru menjelaskan materi, memberikan contoh soal, kemudian memberikan latihan. Setiap soal latihan yang dianggap membutuhkan waktu lama untuk mengerjakannya, soal tersebut akhirnya dijawab bersama-sama di papan tulis. Hasil belajar matematika siswa masih rendah dan masih belum sesuai dengan yang diharapkan. Hal ini dibuktikan dengan rendahnya nilai Ulangan Akhir Semester (UAS) siswa di semester ganjil. Banyak siswa yang nilainya masih di bawah Kriteria Ketuntasan Minimal (KKM). Walaupun sudah direkapitulasi dengan nilai harian tetapi masih tetap rendah. Berikut data nilai UAS semester ganjil tahun ajaran 2017/2018.

Tabel 1. Data Nilai UAS Semester Ganjil

\begin{tabular}{cccccccc}
\hline Kelas & $\begin{array}{c}\text { Nilai } \\
\text { Rata-rata } \\
\text { Kelas }\end{array}$ & $\begin{array}{c}\text { Tuntas } \\
(\text { Siswa) }\end{array}$ & $\begin{array}{c}\text { Tuntas } \\
(\%)\end{array}$ & $\begin{array}{c}\text { Tidak } \\
\text { Tuntas } \\
(\text { siswa) }\end{array}$ & $\begin{array}{c}\text { Tidak } \\
\text { Tuntas } \\
(\%)\end{array}$ & KKM & Ket \\
\hline XAk & 54,16 & 0 & 0 & 6 & 100 & 70 & Tidak tuntas \\
XTKJ & 43,07 & 2 & 15,3 & 11 & 84,7 & 70 & Tidak tuntas \\
Gabungan & 46,57 & 2 & 10,5 & 17 & 89,5 & & Tidak tuntas \\
\hline
\end{tabular}

Sumber : Guru matematika SMKIT Darussalam Boarding School 01 Batam 
Karlina dan Amelia: Efektivitas Model Pembelajaran Kooperatif ...

Berdasarkan tabel hasil belajar siswa di atas yang menunjukan bahwa rata-rata UAS kelas X masih di bawah KKM. Dimana 6 siswa mendapat nilai UAS di bawah KKM di kelas XAK dan untuk kelas X TKJ hanya 2 siswa yang nilai UAS nya melampaui KKM. Berdasarkan permasalahan di atas, barbagai cara bisa dilakukan guru untuk meningkatkan hasil belajar siswa. Salah satunya dengan cara menerapkan model pembelajaran Snowball Throwing. Model pembelajaran Snowball Throwing adalah salah satu tipe model pembelajaran Kooperatif yang bertumpu pada kerja kelompok kecil. Tujuan dari model pembelajaran kooperatif adalah memotivasi siswa untuk saling membantu meningkatkan kemampuan anggota kelompok. Pada model pembelajaran Snowball Throwing siswa dituntut untuk dapat menguasai materi, berfikir kreatif, dan bertanggungjawab dalam melaksanakan tugas yang diberikan guru. Model pembelajaran ini dilakukan dengan cara membagi siswa menjadi beberapa kelompok belajar kecil. Semua siswa bertanggungjawab untuk ketuntasan materi pelajaran, dimana setiap siswa diberi kesempatan untuk membuat dan menjawab pertanyaan sesuai materi yang dipelajari.

Model pembelajaran Snowball Throwing merupakan pengembangan dari model pembelajaran diskusi dan merupakan bagian dari model pembelajaran kooperatif (Soimin, 2016:174). Snowball secara etimologi berarti bola salju, sedangkan Throwing artinya melempar. Snowball Throwing secara keseluruhan dapat diartikan melempar bola salju. Dalam pembelajaran Snowball Throwing, bola salju merupakan kertas yang berisi pertanyaan yang dibuat oleh siswa kemudian dilempar kepada temannya sendiri untuk dijawab (Hamdayama, 2015:158). Adapun langkah-langkah model pembelajaran Sbowball Throwing menurut (Kurniasih \& Sani, 2016:78) sebagai berikut :

1. Guru menyampaikan materi yang akan disajikan. Cukup beberapa menit saja.

2. Guru membentuk kelompok dan memanggil masing-masing ketua kelompok untuk memberikan penjelasan tentang materi.

3. Masing-masing ketua kelompok kembali ke kelompoknya masing-masing, kemudian menjelaskan materi yang disampaikan guru kepada anggota kelompoknya.

4. Masing-masing siswa diberi satu lembar kertas untuk menuliskan pertanyaan apa saja yang menyangkut materi yang sudah dijelaskan ketua kelompok.

5. Kertas yang berisi pertanyaan tersebut dibuat seperti bola salju dan dilempar dari satu siswa ke siswa lainnya selama 5 menit.

6. Setelah siswa mendapat satu bola atau satu pertanyaan diberikan kesempatan kepada siswa untuk menjawab pertanyaan yang tertulis dalam kertas berbentuk bola tersebut secara bergantian. 
Karlina dan Amelia: Efektivitas Model Pembelajaran Kooperatif ...

7. Setelah semuanya mendapat giliran, kemudian guru memberikan kesimpulan materi hari itu dan melakukan evaluasi jika dibutuhkan, dan kemudian menutup pelajaran.

Berdasarkan hasil penelitian Yuliati (2015) diperoleh hasil bahwa penggunaan model pebelajaran kooperatif tipe Snowball Throwing pada materi sistem pertidaksamaan linear dapat meningkatkan hasli belajar siswa XI-IS-2 SMA Negeri 7 Banda Aceh. Hasil post--test pada siklus pertama $40 \%$ yang tuntas dan pada siklus kedua mengalami peningkatan sebesar 53\% yaitu menjadi 93\% serta terjadi peningkatan efektifitas siswa XI-IS-2 SMA Negeri 7 Banda Aceh dalam mengikuti pembelajaran. Peningkatan ini terjadi karena siswa sudah termotivasi dan merasa senang serta antusias terhadap model pembelajaran kooperatif tipe Snowball Throwing.

Menurut penelitian yang dilakukan Firdaus (2016) ditinjau dari ketuntasan belajar siswa, aktivitas siswa, kemampuan guru dalam mengelola pembelajaran dan respon positif siswa maka penerapan model pembelajaran kooperatif tipe Snowball Throwing pada siswa kelas VIII SMP Negeri 13 Makassar lebih efektif jika dibandingkan dengan penerapan metode ekspositori untuk pokok bahasan sistem persamaan linear dua variabel (SPLDV). model pembelajaran kooperatif tipe Snowball Throwing dapat meningkatkan hasil belajar matematika siswa. Sedangkan menurut penelitian yang dilakukan oleh Gusmania \& Wahyudha (2015) terjadi peningkatan aktifitas siswa dalam pelajaran matematika melalui model pembelajaran question students have dengan teknik snowball throwing di kelas eksperimen. Berdasarkan hasil penelitian tersebut dapat disimpulkan bahwa pembelajaran matematika melalui model pembelajaran question students have dengan teknik snowball throwing terdapat pengaruh terhadap hasil belajar kelas VII SMP Ananda Batam tahun pelajaran 2013/2014.

\section{METODOLOGI (Material dan Metode)}

Penelitian ini mengguanakan metode penelitian eksperimen. Menurut Sugiyono (2012:107), metode penelitian eksperimen adalah metode penelitian yang digunakan untuk mencari pengaruh perlakuan tertentu terhadap yang lain dalam kondisi yang terkendalikan. Jenis penelitian yang digunakan adalah Pre Eksperimental yaitu belum merupakan eksperimen sungguh-sungguh dikarenakan masih terdapat variabel luar yang ikut mempengaruhi (Lestari \& Yudhanegara, 2017:121), dengan desain penelitian One-Group Pre-test-Post-test Design dimana dalam penelitian ini terdapat suatu kelompok yang diberi perlakuan (treatment), dan selanjutnya diobservasi hasilnya. Perlakuan (treatment) sebagai variabel independen dan hasil yang diobservasi sebagai variabel dependen. Pengambilan 
Karlina dan Amelia: Efektivitas Model Pembelajaran Kooperatif ...

sampel dari pupolasi yang ada menggunakan teknik sampling jenuh, dimana sampling jenuh adalah teknik pengambilan sampel bila semua populasi digunakan sebagai sampel (Sugiyono, 2012:124).

Untuk memperoleh data hasil belajar yang dibutuhkan maka instrumen yang digunakan dalam penelitian ini adalah tes untuk mengetahui tingkat pencapaian hasil belajar siswa yaitu menggunakan pre-test dan post-test. Bentuk dari pre-test dan post-test yang diberikan berupa esai yang berhubungan dengan materi yang telah diajarkan selama pembelajaran. Soal pretest dan post-test masing-masingnya diberikan sebanyak 8 soal untuk uji coba. Uji coba soal dilakukan beberapa tahap yaitu uji validitas mengunakan rumus koefisien korelasi Product Moment Pearson, kemudian terhadap soal yang valid diukur tingkat kesukaran dan daya pembeda (Sundayana, 2014). Terakhir, dilakukan uji reliabilitas menggunakan rumus Alpha Cronbach.

Setelah dilakukan uji coba instrumen, tahap selanjutnya dilakukan pre-test dan posttest. Setelah itu dilakukan analisis data menggunakan uji normalitas dan homogenitas. Pengujian normalitas menggunakan Kolmogorov Smirnov dan uji homogenitas dengan menggunakan Levene Statistik (Lestari \& Yudhanegara, 2017:248).

\section{PEMBAHASAN}

\section{Deskripsi Data}

Data yang diperoleh dari hasil penelitian ini adalah kuantitatif. Deskripsi data yang disajikan adalah hasil belajar matematika siswa kelas eksperimen. Data yang diberikan tersebut diperoleh dari hasil pre-test dan post-test yang diberikan pada kelas eksperimen.

\section{Uji Prasyarat}

Uji normalitas adalah data adalah uji prasyarat tentang kelayakan data untuk dianalisis dengan menggunakan statistik parametrik atau statistik nonparametrik. Melalui uji ini, sebuah data hasil penelitian dapat diketahui bentuk distribusi normal atau tidak normal. Pengujian normalitas dilakukan dengan bantuan IBM SPSS Statistic Versi 20 menggunakan Kolmogorov Smirnov dengan taraf signifikan 5\% (Lestari \& Yudhanegara, 2017: 245), dengan kriteria pengujian jika nilai sig $>$ a maka $\mathrm{H}_{0}$ diterima atau data berdistribusi normal, jika nilai $\operatorname{sig}<\mathrm{a}$ maka $\mathrm{H}_{0}$ ditolak atau data tidak berdistribusi normal (Riadi, 2016: 122).

Tabel 2. Output Normalitas Data Pre-test

\begin{tabular}{lccc}
\hline & \multicolumn{3}{c}{ Kolmogorov-Smirnov $^{\boldsymbol{a}}$} \\
\cline { 2 - 4 } & Statistic & Df & Sig. \\
\hline pre-test & .173 & 19 & .135 \\
Post-test & .148 & 19 & .200 \\
\hline
\end{tabular}


Karlina dan Amelia: Efektivitas Model Pembelajaran Kooperatif ...

Dari hasil output di atas dapat dilihat nilai Sig. pre-test pada kolom Kolmogorov Smirnov adalah 0,135. Sig $>\alpha$ yaitu $0,135>0,05$ berarti $\mathrm{H}_{0}$ diterima atau data pre-test berdistribusi normal. Dan nilai Sig. post-test pada kolom Kolmogorov Smirnov adalah 0,200 yang berarti data post-test berdistribusi normal.

Uji homogenitas dilakukan untuk mengetahui apakah variansi data dari sampel yang dianalisis homogen atau tidak. Uji homogenitas data yang dilakukan dalam penelitian ini Levene Statistik (Lestari \& Yudhanegara, 2017:248). Untuk menguji homogenitas dalam penelitian ini menggunakan bantuan IBM SPSS Statistic Versi 20 Dasar pengambilan keputusan dalam uji homogenitas adalah:

1. Jika nilai sigifikansi $<0,05$ maka dikatakan bahwa varian dari dua atau lebih kelompok populasi data adalah tidak sama.

2. Jika nilai signifikansi $>0,05$ maka dikatakan bahwa varian dari dua atau lebih kelompok populasi data adalah sama.

Tabel 3. Output Uji Homogenitas

\begin{tabular}{cccc}
\hline Levene Statistic & df1 & df2 & Sig. \\
\hline .004 & 1 & 36 & .948 \\
\hline
\end{tabular}

Berdasarkan tabel di atas dapat dilihat bahwa angka signifikansi dari kedua variabel tersebut lebih dari sama dengan taraf signifikansi yang telah ditentukan yaitu 0,05. Maka dapat disimpulkan bahwa data penelitian ini bersifat homogen setelah masing-masing data diuji dengan menggunakan Levene.

\section{Uji Hipotesis}

Untuk menguji hipotesis dalam penelitian ini digunakan uji t dua sampel berkorelasi untuk mengetahui apakah terdapat perbedaan pengaruh terhadap hasil belajar matematika siswa sebelum dan setelah diberi perlakuan (Sugiyono, 2012:122). Dengan kriteria pengujian hipotesisnya adalah jika $P$-value $>\alpha$ maka $\mathrm{H}_{0}$ diterima, dan jika $P$-value $\leq \alpha$ maka $\mathrm{H}_{0}$ ditolak (Lestari \& Yudhanegara, 2017:274).

Tabel 4. Output Uji Hipotesis

\begin{tabular}{|c|c|c|c|c|c|c|c|}
\hline \multicolumn{5}{|c|}{ Paired Differences } & \multirow{3}{*}{$T$} & \multirow{3}{*}{$D f$} & \multirow{3}{*}{$\begin{array}{l}\text { Sig. }(2- \\
\text { tailed })\end{array}$} \\
\hline \multirow[t]{2}{*}{ Mean } & \multirow{2}{*}{$\begin{array}{c}\text { Std. } \\
\text { Deviation }\end{array}$} & \multirow{2}{*}{$\begin{array}{c}\text { Std. } \\
\text { Error } \\
\text { Mean }\end{array}$} & \multicolumn{2}{|c|}{$\begin{array}{c}\text { 95\% Confidence Interval of } \\
\text { the Difference }\end{array}$} & & & \\
\hline & & & Lower & Upper & & & \\
\hline-32.421 & 4.286 & .983 & -34.487 & -30.355 & -32.974 & 18 & .000 \\
\hline
\end{tabular}


Karlina dan Amelia: Efektivitas Model Pembelajaran Kooperatif ...

Berdasarkan hasil pengujian hipotesis dengan uji $\mathrm{T}$ dua sampel berkorelasi diperoleh nilai $P$-value $\leq \alpha$ dimana $\alpha=0.05$, maka $\mathrm{H}_{0}$ ditolak yang berarti hasil belajar matematika siswa sesudah diterapkan model pembelajaran Snowball Throwing efektif dibandingkan sebelum diterapkan model pembelajaran Snowball Throwing. Berdasarkan hasil uji hipotesis diperoleh bahwa hasil belajar matematika siswa sesudah diterapkan model pembelajaran snowball throwing lebih baik atau efektif dibandingkan sebelum diterapkan model pembelajaran snowball throwing.

\section{Pembahasan}

Pada pertemuan pertama dan kedua guru masih mengalami kendala karena masih banyak siswa yang belum memahami bagaimana menyelesaikan soal-soal di LKS, oleh sebab itu peneliti berusaha memotivasi siswa dengan memberikan semangat dan membimbing siswa untuk memudahkan mereka menyelesaikan soal-soal yang ada, karena siswa masih belum dapat menyelesaikan soal-soal. Peneliti menemukan kendala lain yaitu waktu pembelajaran yang kurang cukup pada pertemuan pertama, sedangkan pada pertemuan kedua, ketiga dan keempat waktu pembelajaran yang diberikan cukup untuk melakukan pembelajaran dengan model pembelajaran snowball throwing karena mereka dapat lebih mudah untuk menyelesaikan soal-soal walaupun masih memerlukan bimbingan guru.

Proses pembelajaran yang dilakukan pada pertemuan pertama, kedua dan ketiga sama seperti yang sudah dijelaskan sebelumnya, pada pertemuan keempat guru memberi soal berupa permasalahan dalam kehidupan nyata yang dapat dihitung menggunakan matriks.

Berdasarkan pengalaman peneliti selama melakukan penelitian menggunakan model pembelajaran snowball throwing pada pertemuan pertama, siswa sudah menunjukkan keaktifan dibanding sebelum diterapkan model pembelajaran snowball throwing. Pada pertemuan kedua, siswa telah menunjukkan peningkatan hasil belajar. Hal ini karena guru sudah mampu meningkatkan interaksi siswa dibandingkan pada pertemuan pertama. Siswa terlihat menikmati dan fokus pada pembelajaran dan terlihat cukup antusias dalam mengikuti kegiatan pembelajaran. Selanjutnya siswa telah dapat termotivasi belajarnya dengan penggunaan model pembelajaran snowball throwing. Siswa juga merasa senang dan mudah memahami materi yang telah diajarkan. Begitupun pada pertemuan ketiga dan keempat pembelajaran berlangsung dengan aktif. Sehingga ketika guru memberikan soal post-test ratarata nilai hasil belajar siswa mengalami peningkatan dibandingkan dengan rata-rata nilai soal pre-test yang diberikan kepada siswa sebelum diterapkan model pembelajaran snowball throwing. 
Karlina dan Amelia: Efektivitas Model Pembelajaran Kooperatif ...

Nilai hasil belajar matematika siswa berdasarkan indikator pembelajaran yang setiap soal memuat satu indikator pembelajaran, rata-rata hasil pembelajaran matematika dapat dilihat pada tabel berikut:

Tabel 5. Data Hasil Belajar Matematika Siswa Berdasarkan Indikator

\begin{tabular}{clcccc}
\hline No. & Indikator Pembelajaran & Pre-test & $\begin{array}{c}\text { Persentase } \\
\mathbf{( \% )}\end{array}$ & \begin{tabular}{c} 
Post-test \\
\hline 1
\end{tabular} & $\begin{array}{c}\text { Persentase } \\
(\%)\end{array}$ \\
\hline & $\begin{array}{l}\text { Menentukan operasi pada } \\
\text { matriks. }\end{array}$ & 0.59 & 58.95 & 0.82 & 81.58 \\
& $\begin{array}{l}\text { Menentukan kesamaan dua } \\
\text { matriks dan transpose pada }\end{array}$ & 0.46 & 46.05 & 0.87 & 87.11 \\
& $\begin{array}{l}\text { matriks. } \\
3\end{array}$ & 0.56 & 55.53 & 0.82 & 82.11 \\
4 & $\begin{array}{l}\text { Menentukan invers matriks. } \\
\text { Membuat model matematika } \\
\text { dari masalah yang berkaitan } \\
\text { dengan konsep matriks }\end{array}$ & 0.47 & 46.58 & 0.83 & 82.50 \\
\hline
\end{tabular}

Berdasarkan tabel 5 di atas terlihat bahwa indikator pertama pada pre-test menunjukan angka 0,59 dengan 58,95\% sedangkan pada post-test menunjukan angka 0,82 dengan persentase $81,58 \%$ yang berarti terdapat peningkatan pada indikator pertama. Indikator kedua rata-rata hasil belajar siswa pada pre-test menunjukan angka 0,46 dengan persentase $46,05 \%$ sedangkan pada post-test menunjukan angka 0,87 dengan persentase $87,11 \%$, yang berarti pada indikator kedua juga mengalami peningkatan. Indikator ketiga pada pre-test menunjukan angka 0,56 dengan persentase 55,53\% sedangkan pada post-test menunjukan angka 0,82 dengan persentase $82,11 \%$ yang menunjukan bahwa indikator ketiga juga mengalami peningkatan. Selanjutnya indikator keempat pada pre-test menunjukan angka 0,47 dengan persentase $46,58 \%$ sedangkan pada post-test menunjukan angka 0,83 dengan persentase $82,50 \%$, yang berarti indikator keempat juga mengalami peningkatan. Kemudian dari hasil perhitungan nilai N-Gain diperoleh 8 siswa yang mengalami peningkatan tinggi dan 11 siswa mengalami peningkatan sedang.

Firdaus (2016:72) menyatakan dalam penelitiannya penerapan model pembelajaran kooperatif tipe snowball throwing pada siswa kelas VIII SMP Negeri 13 Makassar lebih efektif jika dibandingkan dengan penerapan metode ekspositori untuk pokok bahasan sistem persamaan linear dua variabel (SPLDV). Model pembelajaran kooperatif tipe snowball throwing dapat meningkatkan hasil belajar matematika siswa. Selain itu siswa juga mampu berbaur, dan memotivasi teman yang lain dan tidak merasa dibeda-bedakan. Keaktifan pun terlihat dengan antusias siswa dalam bertanya dan menjawab pertanyaan. Oleh karena itu, 
Karlina dan Amelia: Efektivitas Model Pembelajaran Kooperatif ...

pembelajaran kooperatif tipe snowball throwing sangat membantu siswa dalam meningkatkan hasil belajar matematika siswa.

\section{KESIMPULAN}

Berdasarkan pengujian hipotesis yang dilakukan menggunakan uji $\mathrm{T}$ dua sampel berkorelasi diperoleh nilai sig. $(0.00) \leq \alpha(0,05)$ dapat disimpulkan model pembelajaran kooperatif tipe snowball throwing efektif terhadap hasil belajar matematis siswa kelas XI SMKIT DBS 01 Batam. .

\section{REFERENSI}

Firdaus, A. M. (2016). Efektivitas Pembelajaran Matematika Melalui Penerapan Model Pembelajaran Kooperatif Snowball Throwing. Beta, 9(1), 61-74.

Gusmania, Y dan Wahyudha, R. (2015). Penerapan Model Pembelajaran Question Students Have Dengan Teknik Snowball Throwing Terhadap Hasil Belajar Matematika Siswa Kelas VII SMP Ananda Batam Tahun Pelajaran 2013/2014. Pythagoras, 4(2): 56-61.

Hamdayama, J. (2015). Model dan Metode Pembelajaran Kreatif dan Berkarakter. bogor: Ghalia Indonesia.

Kurniasih, I., \& Sani, B. (2016). Ragam Pengembangan Model Pembelajaran untuk Meningkatkan Profesionalitas Guru. Jakarta: Kata Pena.

Lestari, K. E., \& Yudhanegara, M. (2017). Penelitian Pendidikan Matematika. Bandung: Rafika Aditama.

Munawaroh, M., \& Alamuddin, A. (2014). Pengaruh Penerapan Model Pembelajaran Snowball Throwing Terhadap Hasil Belajar Matematika Siswa dengan Pokok Bahasan Relasi dan Fungsi. EduMa, 163-173.

Riadi, E. (2016). Statistika Penelitian (Analisis Manual dan IBM SPSS). Yogyakarta: ANDI.

Soimin, A. (2016). Model Pembelajaran Inovatif dalam Kurikulum 2013. Yogyakarta: ARRUZZ MEDIA.

Sugiyono. (2012). Metode Penelitian Pendidikan. Bandung: Alfabeta.

Suhendri, H. (2012). Pengaruh Kecerdasan Matematis-Logis dan Kemandirian Belajar Terhadap Hasil Belajar Matematika. Formatif 1 (1), 29-39.

Sundayana, R. (2014). Statistika Penelitian Pendidikan. Bandung: Alfabeta.

Yuliati. (2015). Efektivitas Penggunaan Model Kooperatif Tipe Snowball Throwing untuk Meningkatkan Hasil Belajar Siswa. Peluang, 3(2), 65-78. 